Witold Jarno

Uniwersytet Łódzki

ORCID ID: 0000-0002-5845-6057
OBLICZA WOJNY

TOM $2 \cdot A R M I A K O N T R A N A T U R A$

ŁÓDŹ 2020 • ISBN 978-83-8220-057-7 • s. 225-251

http://dx.doi.org/10.18778/8220-057-7.11

\title{
PRZEMARSZ 3 DYWIZJI STRZELCÓW POLSKICH Z JELNI DO ŻŁOBINA W LUTYM 1918 ROKU
}

Streszczenie. Artykuł opisuje mało znany epizod z dziejów polskich formacji wojskowych w Rosji w latach I wojny światowej. Był nim przemarsz 3 Dywizji Strzelców Polskich w lutym 1918 r. z Jelnii (w pobliżu Smoleńska) do Żłobina, gdzie koncentrował się cały I Korpus Polski dowodzony przez gen. Józefa Dowbora Muśnickiego. Przemarsz 3 Dywizji Strzelców Polskich był wyjątkowy w historii Wojska Polskiego, gdyż odbywał się w bardzo trudnych warunkach pogodowych - poprzez zaspy śnieżne i przy mrozie dochodzącym nocami do minus $30^{\circ} \mathrm{C}$. Żołnierze dywizji maszerowali przez tereny zamieszkane przez wrogo nastawioną do nich ludność - walcząc stale z oddziałami bolszewickimi, które usiłowały zatrzymać i rozbroić polską dywizję. Jej żołnierze stoczyli z wrogiem szereg starć, w tym największy i najkrwawszy bój pod Pobołowem. W ciągu niemal trzech tygodni żołnierze 3 Dywizji Strzelców Polskich przeszli ponad $400 \mathrm{~km}$, docierając pod koniec lutego w rejon Żłobina. Tu połączyli się z I Korpusem Polskim w Rosji - kończąc swą epopeję będącą dowodem wielkiego poświęcenia żołnierza polskiego dla Ojczyzny.

Słowa kluczowe: polskie formacje wojskowe w Rosji, I Korpus Polski w Rosji, 3 Dywizja Strzelców Polskich, I wojna światowa

Polskie formacje wojskowe w Rosji w czasie I wojny światowej nadal nie doczekały się pełnego naukowego opracowania, choć oczywiście wiele już na ten temat napisano. Jednym $z$ takich słabo przebadanych tematów jest przemarsz 3 Dywizji Strzelców Polskich w lutym 1918 r. z Jelni w okolice Żłobina, gdzie dołączyła ona do głównych sił I Korpusu Polskiego w Rosji. Przemarsz dywizji stał się słynny z uwagi na warunki pogodowe, w jakich się odbywał, jak również zagrożenie ze strony oddziałów bolszewickich, próbujących go uniemożliwić. Celem niniejszego tekstu jest ukazanie przegrupowania polskiej dywizji oraz 
warunków, w jakich przebiegało. Zagadnienia te omówione zostały w głównej mierze na podstawie materiałów archiwalnych zgromadzonych w Centralnym Archiwum Wojskowym, choć trzeba dodać, iż z samego przemarszu dywizji nie zachowały się żadne dokumenty.

Dzieje polskich formacji wojskowych w Rosji w czasie I wojny światowej sięgają sierpnia 1914 r., kiedy to zaczęto w Puławach formować - z inicjatywy Witolda Ostoi-Gorczyńskiego - Legion Puławski. Napływ ochotników był jednak niewielki, pomimo poparcia tej inicjatywy przez ugrupowania polityczne o orientacji prorosyjskiej. 25 listopada 1914 r. utworzyły one Komitet Narodowy Polski z Romanem Dmowskim na czele. Pomimo wielu trudności, w styczniu 1915 r. zaczęto w Lublinie organizować drugi legion, który przeszedł do historii jako Legion Lubelski. Miesiąc później na bazie obu legionów utworzono 104 Brygadę Pospolitego Ruszenia, której dowództwo objął gen. Piotr Szymanowski. Istnienie brygady trwało jednak krótko, gdyż już 20 lipca tego roku została rozwiązana, pozostałości zaś Legionu Puławskiego (zwanego teraz Batalionem Lubelskim) skierowano do walki, w trakcie których poniósł on duże straty. We wrześniu 1915 r. batalion - wyczerpany działaniami wojennymi - wycofano do twierdzy w Bobrujsku, co zapoczątkowało kolejny etap w procesie budowy polskich formacji wojskowych w Rosji ${ }^{1}$.

Pomimo niechęci władz rosyjskich, zabiegi polskich ugrupowań politycznych, zmierzające do rozbudowy polskich formacji wojskowych, zakończyły się powodzeniem. Dnia 24 września 1915 r. car Mikołaj II wyraził zgodę na powołanie Brygady Strzelców Polskich, której dowództwo objął wspomniany gen. P. Szymanowski, a następnie gen. Antoni Sławoczyński (od 7 kwietnia 1916) i gen. Bolesław Olszewski (od 27 września 1916). Brygadę formowano w Bobrujsku a w jej składzie znalazły się cztery bataliony, którymi dowodzili: płk Jan Rządkowski, płk Lucjan Żeligowski, płk Bolesław Frej i płk Znamierowski (imię nieznane). Od wiosny 1916 r. do stycznia 1917 r. oddziały brygady walczyły na froncie rosyjsko-niemieckim - po czym zostały z niego wycofane w związku z decyzją władz rosyjskich o jej przeformowaniu w Dywizję

\footnotetext{
${ }^{1}$ M. Wrzosek, Wojskowość polska podczas pierwszej wojny światowej (1914-1918), [w:] Zarys dziejów wojskowości polskiej w latach 1864-1939, red. P. STAWECKI, Warszawa 1990, s. 190-192; W.Lipiński, Walkazbrojna o niepodlegtość Polski w latach 1905-1918, Warszawa 1990, s. 231-239. Szerzej o Legionie Puławskim i jego walkach vide: J. RząDKowski, Pierwszy Legion Putawski, Warszawa 1925, s. 5 i nast.; H. BAGiński, Wojsko Polskie na Wschodzie 1914-1920, Warszawa 1921, s. 11-39.
} 
Strzelców Polskich. Nowo powstająca w rejonie Kijowa dywizja - dowodzona przez gen. Tadeusza Bylewskiego - w czerwcu 1917 r. liczyła już około 12000 ludzi, lecz pod wpływem rozwijającej się agitacji bolszewickiej część żołnierzy uległa zrewoltowaniu, przez co jej liczebność zmalała do około 2500 żołnierzy².

Obalenie caratu zapoczątkowało nowy okres w polskim wysiłku zbrojnym podczas I wojny światowej. W całej Rosji zaczęły powstawać Związki Wojskowe Polaków, w których działalności ukształtowały się dwa zasadnicze kierunki: pierwszy eksponował zadania opiekuńczo-wychowawcze, drugi zaś - rozbudowę formacji wojskowych. Na I Zjeździe Wojskowych Polaków w Piotrogrodzie w czerwcu 1917 r. powstał Naczelny Polski Komitet Wojskowy (potocznie nazywany Naczpolem) pod przewodnictwem Władysława Raczkiewicza, popierający ideę rozbudowy polskich formacji wojskowych w Rosji. Dążenia Polaków do rozbudowy narodowych formacji wojskowych spotkały się początkowo ze sprzeciwem rosyjskiego Rządu Tymczasowego, który w sierpniu 1917 r. zgodził się jedynie na powołanie I Korpusu Polskiego, którego dowódcą został gen. Józef Dowbor Muśnicki. Trzeba tu dodać, że za czasów Rządu Tymczasowego polskie formacje wojskowe w Rosji były traktowane jako część składowa armii rosyjskiej i dopiero po objęciu władzy przez bolszewików stawały się one w coraz większym zakresie samodzielne ${ }^{3}$.

Formowany na Białorusi I Korpus Polski - mający się składać z trzech dywizji piechoty, trzech brygad artylerii, pułku jazdy oraz pułku inżynieryjnego ${ }^{4}$ - zaczęto tworzyć na bazie Dywizji Strzelców Polskich, którą przeorganizowano na 1 DSP dowodzoną przez gen. Gustawa Ostapowicza. Pozostałe dwie dywizje miały powstać w dalszej kolejności, co nie było zadaniem prostym z uwagi na poważne trudności natury kadrowej, organizacyjnej i materiałowej. Dodatkowym problemem był fakt, że jednostki korpusu zostały rozlokowane na rozległym obszarze Białorusi, przez co rejony ich formowania dzieliły duże odległości. W szczególnie trudnej sytuacji znalazła się nowo tworzona 3 DSP,

2 M. WrzoseK, op. cit., s. 192-194; W. LipińsKi, op. cit., s. 240-243; H. BAGIŃsKi, op. cit., s. $43-62$.

3 Pod koniec 1917 r. opierając się na tych zasadach zaczęto formować II Korpus Polski gen. Jana Stankiewicza w Besarabii oraz III Korpus Polski gen. Eugeniusza Michaelisa na Ukrainie.

${ }^{4}$ M. Wrzosek, op. cit., s. 194-195; IDEM, Polskie korpusy wojskowe w Rosji w latach 1917-1918, Warszawa 1969, s. 28-37; H. BAGiński, op. cit., s. 149-152; H. Orleański, N.J. Hertz, I Korpus Polski. Rys historyczny, Warszawa 1938, s. 7-10. 
którą miano zorganizować w rejonie Jelni, oddalonej o ponad 400 km od Bobrujska, który stał się niebawem miejscem postoju I Korpusu Polskiego5.

Formowanie 3 DSP miało odbyć się z wykorzystaniem powstającej w tym czasie - w rejonie Mołodeczna na bliskim zapleczu frontu rosyjsko-niemieckiego - 2 Kaukaskiej Dywizji Grenadierów, która w wyniku pogłębiającego się chaosu i rozprężenia armii rosyjskiej uległa demoralizacji i pod koniec czerwca 1917 r. - rozkazem dowództwa rosyjskiego Frontu Zachodniego - została rozwiązana. Wykorzystując część kadry oficerskiej oraz odebraną broń rozwiązanej 2 Kaukaskiej Dywizji Grenadierów postanowiono w lipcu 1917 r. - w ramach rozbudowy I Korpusu Polskiego - sformować 3 DSP. Początkowo miało to nastąpić w rejonie na północ od Mińska, gdzie dowództwo nowej dywizji miał objąć generał Mikołaj Konstantinowicz Gedewanow, gruziński książę, który później pełnił obowiązki szfa sztabu 2 Kaukaskiej Dywizji Grenadierów ${ }^{6}$. Na jej oficerach sztabowych oparty został również sztab 3 DSP. W skład dywizji weszły cztery pułki strzelców, utworzone na bazie dawnych pułków wspomnianej dywizji kaukaskiej: 9 ps - to dawny 23 Pułk Grenadierski), 10 ps - to były 24 Pułk Grenadierski, 11 ps - to były 703 Pułk Grenadierski oraz 12 ps - to dawny 704 Pułk Grenadierski. Ponadto w skład 3 DSP miało wejść szereg innych nowych oddziałów, jak np. III Brygada Artylerii, 3 Rezerwowy Dywizjon Parkowy, kompania inżynieryjna, szpital polowy oraz niezbędne pododdziały tyłowe. Ponieważ żołnierzy polskiej narodowości (zarówno oficerów, jak i szeregowych) było w formowanej dywizji niewielu, więc przez kilka kolejnych miesięcy dominowali w niej żołnierze rosyjscy i dopiero jesienią 1917 r. została ona „spolonizowana”. Proces organizowania 3 DSP w rejonie Mińska odbywał się w trudnych warunkach. Odczuwano brak żołnierzy, toteż w praktyce dywizja miała początkowo charakter kadrowy (liczyła około 2800 ludzi zamiast niemal 17000 przewidzianych etatem) i borykała się z niedostatkiem broni oraz wszelkiego wyposażenia ${ }^{8}$. Dodatkowo przekazana jej - w niewystarczającej ilości - broń strzelecka wymagała w większości napraw, wręcz zaś fatalnie wyglądał stan przydzielonych dywizji koni, które były zaniedbane i niedożywione.

5 W. Lipiński, op. cit., s. 240-258; M. WRZoseK, Wojskowość polska podczas..., s. 195-197; Polskie korpusy wojskowe..., s. 72-83.

${ }^{6}$ http://www.ria1914.info/index.php/Гедеванов Николай Константинович [dostęp: 15 XI 2019].

7 Centralne Archiwum Wojskowe w Wojskowym Biurze Historycznym [dalej: CAW WBH], sygn. I.400.2899, J. КовҮєеСкі, 3 Dywizja Strzelców I-go Polskiego Korpusu w roku 1917 i 1918, k. 8-9.

${ }^{8}$ H. BAGIŃsKi, op. cit., s. 171. 
W okolicy Mińska 3 DSP pozostawała do sierpnia 1917 r., kiedy to wyznaczono dla związków taktycznych I Korpusu Polskiego nowe miejsca formowania: rejon Starego Bychowa - dla 1 DSP, Zubcowa - dla 2 DSP, Jelni - dla 3 DSP, Dorohobużu - dla Brygady Rezerwowej i Witebska - dla oddziałów artylerii. W związku z powyższym, oddziały 3 DSP zostały we wrześniu przewiezione koleją w rejon Jelni, oddalonej od Bobrujska o ponad $400 \mathrm{~km}$. Znaczne oddalenie dywizji od rejonów koncentracji innych jednostek I Korpusu Polskiego rodziło problemy natury organizacyjnej, zwłaszcza w zakresie utrzymania łączności z dowództwem korpusu. Rosyjskie dowództwo Frontu Zachodniego rozlokowanie 3 DSP w rejonie Jelni tłumaczyło faktem, iż to właśnie tam zgromadzono broń i wyposażenie byłej 2 Kaukaskiej Dywizji Grenadierów, które przeznaczono na potrzeby polskiej dywizji. Nadal jednak odczuwała ona poważne braki kadrowe, gdyż 14 grudnia 1917 r. 3 DSP liczyła jedynie około 2500 żołnierzy, w tym 1886 tzw. frontowych ( 490 w 9 ps, 598 w 10 ps, 508 w 11 ps oraz 400 w 12 ps). Po przybyciu do Jelni dowództwo dywizji objął gen. Józef Leśniewski, jego zastępcą został gen. Adolf Kuczewski, szefem sztabu - ppłk Julian Kobyłecki, dowództwa zaś czterech pułków objęli: 9 ps - płk Albin Jasiński, 10 ps - płk Leon Silicki, 11 ps - ppłk Józef Kopytyński i 12 ps - ppłk Wacław Krupowicz?.

Początkowo - ze względu na niewielką liczebność - większość oddziałów dywizji rozlokowano w samym mieście, a jedynie tabor dywizyjny ulokowano około $15 \mathrm{~km}$ od Jelni, gdzie łatwiej było zapewnić aprowizację i furaż dla koni. W nowym rejonie koncentracji dywizji było niespokojnie, gdyż coraz aktywniej działali tu agitatorzy bolszewiccy, ogólny zaś chaos doprowadził do powstania wielu band rabunkowych. Nic dziwnego, że tzw. obywatele ziemscy oraz bogaci mieszczanie z radością przyjęli przybycie polskiej dywizji, spodziewając się, iż dzięki jej obecności ustaną napady i grabieże. Większość z okolicznych właścicieli ziemskich starała się o zakwaterowanie w swoim majątku choćby niewielkiego pododdziału, obiecując w zamian wyżywienie jego żołnierzy. Była

9 CAW WBH, sygn. I.400.2899, J. KoвYŁecki, 3 Dywizja Strzelców..., k. 9-10; CAW WBH, ap. Adolf Kuczewski, sygn. I.480.301, Główna karta ewidencyjna z 1921 r., brak paginy; CAW WBH, ap. Julian Kobyłecki, sygn. I.480.261, Wniosek o odznaczenie Orderem Odrodzenia Polski, brak paginy; CAW WBH, ap. Albin Jasiński, sygn. I.480.223, Wniosek o odznaczenie A. Jasińskiego orderem Virtuti Militari z 20 X 1921 r., k. 5-6; CAW WBH, ap. Leon Silicki, sygn. 7662, Karta kwalifikacyjna dla Komisji Weryfikacyjnej z 1920 r., brak paginy; CAW WBH, ap. Józef Kopytyński, sygn. 5386, Karta ewidencyjna z 1919 r., brak paginy; CAW WBH, ap. Wacław Krupowicz, sygn. 19497, Odpis głównej karty ewidencyjnej z 1925 r., brak paginy; H. BAGIŃsKI, op. cit., s. 173. 
to dla dowództwa dywizji atrakcyjna oferta ze względów aprowizacyjnych, lecz konieczność zapewnienia bezpieczeństwa własnym oddziałom oraz prowadzenia szkolenia - wymagały skoncentrowania dywizji w jednym miejscu. Stąd też w okolicznych majątkach rozlokowano jedynie kilka niewielkich pododdziałów (głównie tyłowych), a wszystkie cztery pułki strzelców pozostały w Jelni. Ze względu na brak koszar żołnierzy zakwaterowano w prywatnych domach, co z jednej strony było dla ich mieszkańców niedogodnością, lecz z drugiej - zabezpieczało ich przed napadami rabunkowymi. Jednak formowanie 3 DSP przebiegało powoli, na co zasadniczy wpływ miały trudności kadrowe zarówno w odniesieniu do oficerów, jak i szeregowych. Ochotniczy system uzupełniania opierał się bowiem na propagandzie prowadzonej poprzez polskich agitatorów rozsyłanych do różnych miast i miasteczek oraz oddziałów armii rosyjskiej, w których rozpowszechniano wśród żołnierzy polskiej narodowości informację o formowaniu wspomnianego korpusu. Ta nieformalna akcja werbunkowa zaczęła powoli przynosić efekty, czego rezultatem był stopniowo wzrastający napływ - m.in. i do 3 DSP - Polaków z armii rosyjskiej. Jednak obok żołnierzy oddanych ideowo sprawie walki o niepodległość Polski, do szeregów dywizji zgłaszali się również agitatorzy bolszewiccy celem szerzenia propagandy komunistycznej mającej doprowadzić do jej dezorganizacji. Agitacja ta nie przyniosła na szczęście większych efektów, sami zaś agitatorzy byli wrogo traktowani przez żołnierzy i musieli uciekać przed pobiciem lub rozstrzelaniem. $\mathrm{Z}$ obawy przed wrogą agitacją dowództwo 3 DSP postanowiło usunąć z szeregów dywizji służących w niej żołnierzy narodowości rosyjskiej, pozostawiając jedynie niewielką grupę Rosjan zamieszkałych przed wybuchem I wojny światowej na terenach dawnej Kongresówki ${ }^{10}$.

Duże problemy towarzyszyły formowaniu w pułkach strzelców pododdziałów konnych wywiadowców (zwiadowców). Ponieważ brakowało odpowiednich koni - dowództwo dywizji zwróciło się do okolicznych właścicieli ziemskich (zarówno Rosjan, jak i Polaków) z propozycją przekazania przez nich koni na potrzeby wspomnianych pododdziałów, dzięki czemu miały one szybko reagować i bronić majątków w razie napadu rabunkowego. Pozyskano w ten sposób około stu kilkudziesięciu koni, co pozwoliło zorganizować przy każdym z czterech pułków strzelców po jednym pododdziale konnych wywiadowców, liczącym

${ }^{10}$ CAW WBH, sygn. I.400.2899, J. KoвYŁeCKI, 3 Dywizja Strzelców..., k. 10. 
po około 30-40 żołnierzy. Odegrały one niebawem ważną rolę w rozpoznawaniu sytuacji wokół Jelni, uprzedzając dowództwo dywizji przed różnymi zagrożeniami oraz przeciwdziałając wystąpieniom zrewoltowanej ludności wiejskiej i napadom band rabunkowych. Panująca w dywizji karność, na tle ulegającej rozprężeniu armii rosyjskiej, czyniła z niej związek taktyczny o poważnej sile bojowej, pomimo wciąż stosunkowo niskich stanów liczebnych. W oddziałach zaprowadzono porządek, żołnierzom zaś nakazano przestrzegać przepisów dyscyplinarnych, za naruszenie których groziła surowa odpowiedzialność. Zakazane zostały wszelkie samowolne rekwizycje i wyrządzanie ludności cywilnej jakichkolwiek krzywd czy szkód majątkowych. Duży nacisk położono również na proces szkolenia żołnierzy, ustalając szczegółowy program ćwiczeń. „Ten wzorowy porządek, karność żołnierzy, ich czysty i dziarski wygląd oraz przyzwoite zachowanie się wobec ludności, robiły wśród niej imponujące wrażenie i wpływały bardzo korzystnie na jej stosunek do dywizji. Toteż ludność miejska chętnie przyjmowała oficerów i żołnierzy na stancję, dożywiała ich i starała się im we wszystkim dogadzać"11.

Pod koniec 1917 r. nastąpiła zmiana na stanowisku dowódcy 3 DSP, gdyż gen. J. Leśniewskiego zastąpił gen. ppor. Wacław Iwaszkiewicz-Rudoszański, były dowódca Finlandzkiej Dywizji Strzelców ${ }^{12}$. Nowy dywizjoner z energią kontynuował prace organizacyjno-szkoleniowe, dążąc zarazem do powiększenia zgromadzonych przez dywizję zapasów żywności, broni, amunicji i niezbędnego wyposażenia. Było to niezwykle ważne, gdyż z uwagi na pogłębiający się chaos w Rosji - obawiano się coraz większych trudności w bieżącym zaopatrzeniu oddziałów dywizji. Dzięki tym działaniom: „pod względem aprowizacji dywizji osiągnięto świetnych rezultatów [świetne rezultaty - W.J.], wtenczas gdy oddziały rosyjskie zaczęły już odczuwać brak żywności, dywizja przez cały czas formowania w Jelni i następnie, aż do chwili połączenia się z Korpusem w rejonie Bobrujska, była zabezpieczona w żywność w takiej mierze, że musiała przed wystąpieniem z Jelni do Bobrujska zlikwidować część zapasów, aby zbytnio nie obciążać swego taboru"13.

${ }^{11}$ CAW WBH, sygn. I.400.2899, J. KовYєескі, 3 Dywizja Strzelców..., k. 11.

12 Szerzej o gen. Wacławie Iwaszkiewiczu-Rudoszańskim vide: W. JARno, Generat Wactaw Iwaszkiewicz-Rudoszański (1871-1922) - zarys biografii, „Acta Universitatis Lodziensis”, Folia Historica 104, 2019, s. 125-146.

13 CAW WBH, sygn. I.400.2899, J. KовҮŁECKI, 3 Dywizja Strzelców..., k. 15. 
Widoczną dla gen. W. Iwaszkiewicza-Rudoszańskiego słabością dywizji był brak artylerii, gdyż ta formowała się w rejonie Witebska. Wobec coraz wyraźniejszej wrogiej postawy lokalnych władz bolszewickich, dowódca I Korpusu Polskiego nakazał w końcu grudnia jej przegrupowanie w rejon Bobrujska. Okazało się to niemożliwe, gdyż bolszewicy odmówili podstawienia transportów kolejowych, po czym rozbroili pododdziały zgromadzone w rejonie m. Krynki. Zanim to nastąpiło gen. W. Iwaszkiewicz-Rudoszański wysłał do formujących się oddziałów artylerii kilkunastu żołnierzy mających przyprowadzić w rejon Jelni choćby jedną baterię armat. Przybyli oni jednak za późno, gdy większość pododdziałów artylerii została już rozbrojona przez bolszewików. W rezultacie 3 DSP nie posiadała jakże potrzebnej artylerii. Dlatego też - celem zwiększenia siły ognia dywizji - podjęto w styczniu $1918 \mathrm{r}$. starania o pozyskanie dodatkowych ciężkich karabinów maszynowych: kilka wykradziono ze zbrojowni smoleńskiej, około zaś dziesięciu z magazynu rosyjskiej Komendy Miasta w Jelni1 ${ }^{14}$.

Przez pierwsze tygodnie pobytu 3 DSP w rejonie Jelni władze rosyjskie nie robiły większych problemów w zakresie jej aprowizacji, co pozwoliło zgromadzić większe zapasy żywności (np. konserw, sucharów, masła, mąki). Sprowadzano ją nie tylko z magazynów znajdujących się w Smoleńsku, skąd dywizja otrzymywała bieżące zaopatrzenie, lecz także z innych rejonów, nieraz znajdujących się w znacznej odległości. Pozyskiwano także ze wszelkich możliwych źródeł karabiny powtarzalne i karabiny maszynowe oraz niezbędną amunicję. Jednak z każdym tygodniem stosunek władz bolszewickich do I Korpusu Polskiego stawał się bardziej wrogi, co skłoniło jego dowódcę do wydania na początku lutego 1918 r. rozkazu o skoncentrowaniu wszystkich podległych oddziałów w rejonie Bobrujska. O ile 1 i 2 DSP rozlokowane były w stosunkowo niewielkiej odległości od twierdzy bobrujskiej, to 3 DSP w rejonie Jelni oraz Brygadę Rezerwową w okolicy Dorohobużu - dzieliło od wspomnianej twierdzy ponad $400 \mathrm{~km}^{15}$.

Generał W. Iwaszkiewicz-Rudoszański - mając informację o nieudanych próbach przejazdu koleją w rejon Bobrujska przez pułki 2 DSP - zrezygnował z transportu kolejowego, który mógł zostać łatwo zablokowany przez

${ }^{14}$ CAW WBH, sygn. I.400.2899, J. КовүŁecki, 3 Dywizja Strzelców..., k. 16-17. Szerzej o losach artylerii I Korpusu Polskiego w Rosji vide: W. KozŁOwski, Artyleria polskich formacji wojskowych podczas I wojny światowej, Łódź 1993, s. 231 i nast.

15 CAW WBH, 11 pułk strzelców [dalej: ps], sygn. I.122.34.74, Rozkaz dowódcy 11 ps z 13 I 1918 r., brak paginy; CAW WBH, sygn. I.400.2899, J. КовүєескI, 3 Dywizja Strzelców..., k. 11-15; H. BAGIŃsKi, op. cit., s. 181-182. 
bolszewików i zdecydował się dokonać nakazanego przegrupowania marszem. Było to niezwykłe wyzwanie z uwagi na warunki pogodowe (trzaskający mróz, zaspy śnieżne na drogach, brak namiotów) oraz wrogi stosunek bolszewików, którzy - z czego dowódca dywizji zdawał sobie sprawę - będą próbować rozbroić polską dywizję. Jej przegrupowanie na odległość ponad $400 \mathrm{~km}$ wymagało przygotowania niezbędnych środków transportowych. Jednak przydatność wozów taborowych w okresie zimowym była ograniczona, gdyż z łatwością grzęzły w śnieżnych zaspach. Najlepiej nadawały się do tego konne sanie, toteż na przełomie stycznia i lutego 1918 r. zaczęto kupować je za gotówkę od okolicznej ludności, jak również wymieniać na nieprzydatne do długiego marszu posiadane wozy taborowe, biedki i powozy. Dzięki temu oddziały 3 DSP zdołały pozyskać około 250 sań konnych, którymi miano przewieźć karabiny maszynowe, niezbędny zapas amunicji i żywności oraz chorych i rannych żołnierzy - zdrowi mieli maszerować na własnych nogach. Oczywiście w niezbędnym zakresie wykorzystano również wozy taborowe. W ramach przygotowań do przemarszu 3 DSP - jej dowódca wydał 25 stycznia 1918 r. rozkaz, w którym nakazał, by do czasu opuszczenia dotychczasowego miejsca zakwaterowania dywizji - oprócz obiadowej normy - wszystkim żołnierzom wydawać dodatkowe przydziały chleba, cukru i konserw ${ }^{16}$.

$\mathrm{Na}$ początku lutego $1918 \mathrm{r}$. bolszewicy podjęli wrogie kroki wobec 3 DSP, zmierzając do jej rozbrojenia. Trafnie działania te opisał por. Tadeusz Ozimek: „W ładze sowieckie przez dłuższy czas miały nadzieję, że uda się im przeciągnąć na swoją stronę 3-cią dywizję i wprowadzić w niej ustrój armii czerwonej, lecz kiedy nadzieje spełzły na niczem, zaczął się atak na 3-cią dywizję ze strony armii czerwonej. 3 lutego 1918 r. gen. Iwaszkiewicz dowiaduje się, że sowiet smoleński postanowił rozbroić polską siłę zbrojną, znajdującą się w m. Jelnia. I w samej rzeczy już 4 lutego artyleria rosyjska wyjechała ze Smoleńska w kierunku Jelni, a w nocy przybywają transporty bolszewickie na stację Glinkę, odległą od Jelni o wiorst osiemnaście"17. Dzięki wywiadowcom rozlokowanym w okolicznych miejscowościach, gen. W. Iwaszkiewicz-Rudoszański szybko dowiedział się tego

16 CAW WBH, sygn. I.400.2899, J. Koвyєecki, 3 Dywizja Strzelców... k. 17; CAW WBH, 3 Dywizja Strzelców Polskich [dalej: DSP], sygn. I.122.18.14, Rozkaz dowódcy 3 DSP z 25 I 1918 r., brak paginy; CAW WBH, 9 ps, sygn. I.122.32.40, Rozkaz dowódcy 9 ps nr 32 z 1 II 1918 r., brak paginy; CAW WBH, 10 ps, sygn. I.122.33.41, Rozkaz dowódcy 3 DSP z 25 I 1918 r., brak paginy.

17 CAW WBH, sygn. I.400.2228, Relacja por. Tadeusza Ozimka o przegrupowaniu 3 DSP z Jelni do Żłobina, k. 1. 
dnia o zbliżaniu się w kierunku Jelni transportu wojsk bolszewickich i nakazał skierować silny podjazd w rejon pobliskiej stacji w m. Glinki celem jego śledzenia oraz w razie potrzeby wysadzenia torów. Oprócz tego, podjazdy z karabinami maszynowymi wysłano na wszystkie drogi prowadzące do Jelni. Jak się niebawem okazało, były to słuszne posunięcia, gdyż poruszający się od strony Smoleńska inny pododdział bolszewicki w rejonie m. Nieżody napotkał polski podjazd i próbował przełamać jego obronę. Twardy opór polskich żołnierzy zmusił wroga do odwrotu, bolszewicy zaś ograniczyli się do obserwacji i nękania polskiego podjazdu, który pozostał na swych pozycjach do czasu wymarszu dywizji z Jelni ${ }^{18}$. To pierwsze starcie zbrojne z bolszewikami tak wspominał por. T. Ozimek: „Dnia 6 lutego padły pierwsze strzały ze strony bolszewików. Było kilku rannych z naszej strony. Dnia 7 lutego oddział naszej piechoty pod dowództwem podporucznika Aleksandra Krawieckiego z 10 pułku strzelców spotkał się pod wsią Nieżodą z dość licznym oddziałem czerwonej gwardii. Stoczono walkę, w której padł dowódca oddziału bolszewickiego Iwanow, członek sowietu moskiewskiego"19.

Po otrzymaniu rozkazu o jak najszybszym przegrupowaniu 3 DSP w rejon Bobrujska, gen. W. Iwaszkiewicz-Rudoszański zawiadomił gen. Józefa Pawłowskiego, dowódcę Brygady Rezerwowej w Dorohobużu, iż została ona podporządkowana 3 DSP. Jednocześnie nakazał brygadzie wyruszyć niezwłocznie - wraz z kilkoma pododdziałami 2 DSP zatrzymanymi na stacji w Dorohobużu - w kierunku Jelni, celem dołączenia do dywizji i wspólnego z nią marszu w stronę Bobrujska. Na przeszkodzie stanęła jednak agitacja bolszewicka, w wyniku której doszło do dezorganizacji - liczącej niemal 700 żołnierzy - brygady, gdyż 2 pułk rezerwowy niemal w całości odmówił wykonania rozkazu o przemarszu do Jelni i pozostał w Dorohobużu. Na skutek tego wydarzenia gen. J. Pawłowski zrezygnował z dowództwa brygady, co tylko pogorszyło sytuację. Zdołano ją częściowo opanować dzięki energii płk. Jakuba Krzysztofa Szyszki-Bohusza - dowódcy 1 pułku rezerwowego, któremu udało zebrać niemal połowę żołnierzy brygady i wyruszyć z nimi w kierunku Jelni. Po drodze dołączyło do nich około 200 żołnierzy z 8 ps (z 2 DSP) z eszelonu zatrzymanego

${ }^{18}$ CAW WBH, sygn. I.400.2899, J. Koвy£ecki, 3 Dywizja Strzelców..., k. 20; H. BAGiŃski, op. cit., s. 244; IDEM, Bohaterski przemarsz III Dywizji z Jelni do Bobrujska, „Wiadomości Wojskowe” 1918, nr 7-8, s. 92.

19 CAW WBH, sygn. I.400.2228, Relacja por. Tadeusza Ozimka..., k. 1. 
na stacji kolejowej w Dorohobożu. Po kilku dniach marszu pozostałości Brygady Rezerwowej dotarły 9 lutego do Jelni, gdzie włączono je do 3 DSP - dzięki czemu liczebność dywizji wzrosła do około 3400 żołnierzy (w tym około 350 oficerów). Zawirowania wokół Brygady Rezerwowej spowodowały opóźnienie wymarszu dywizji o kilka dni ${ }^{20}$.

Przemarsz 3 DSP z Jelni w rejon Bobrujska trzeba była dobrze zaplanować oraz uwzględnić wiele istotnych czynników mogących wpłynąć na jego realizację. „Zamierzony przemarsz dywizji musiał odbyć się w warunkach wyjątkowo trudnych tak pod względem przeszkód, których spodziewano się ze strony wojsk bolszewickich i band chłopskich, jak i warunków klimatycznych i terenowych" ${ }^{21}$. Opracowana przez szefa sztabu dywizji ppłk. J. Kobyłeckiego trasa przemarszu musiała uwzględniać zarówno warunki terenowe, jak i potencjalne zagrożenie ze strony oddziałów bolszewickich. Dlatego też droga przemarszu miała prowadzić - w miarę możliwości - duktami leśnymi, unikając dróg na otwartej przestrzeni. Zarówno potencjalne zagrożenie ze strony bolszewików, jak i uzbrojonych band chłopskich, wymuszało zastosowanie w trakcie przemarszu środków pozwalających dywizji stawić wrogowi opór w każdej chwili i w każdym miejscu. W konsekwencji przyjęta marszruta przewidywała następującą trasę: Jelnia, Bałtutino, stacja kolejowa Poczynek, Chosławicze, Piotrowicze, Klimowicze, Gajszyn, Korma, Ryśkowo, Łuczyn - by przemarsz zakończyć $\mathrm{w}$ rejonie $\mathrm{m}$. Pobołowo, gdzie według posiadanych informacji miały znajdować się już pozycje oddziałów I Korpusu Polskiego.

Całość trasy - liczącej ponad $400 \mathrm{~km}$ - biegła dość urozmaiconym terenem, gdyż od Jelni do m. Chosławicze droga prowadziła po terenie pofałdowanym, lecz pozbawionym większych kompleksów leśnych, co sprzyjało działaniu wrogiej kawalerii. Odcinek ten był dodatkowo niebezpieczny dla przemarszu, gdyż prowadził pomiędzy miasteczkiem Rosław a Smoleńskiem, w których stacjonowały znaczne siły bolszewickie. Mogły one - wykorzystując biegnącą pomiędzy tymi miastami linię kolejową oraz równoległą do niej szosę - łatwo zagrodzić drogę polskiej dywizji. Dalsza trasa - aż do Dniepru - prowadziła gęstymi lasami, co utrudniało wykrycie ruchów dywizji oraz uniemożliwiało

${ }^{20}$ CAW WBH, sygn. I.400.2228, Relacja por. Tadeusza Ozimka..., k. 1-2; H. BAGIŃski, Wojsko polskie..., s. 188-190 i 244-247; IDEM, Bohaterski przemarsz..., s. 92-93; H. ORLEAŃski, N.J. HerTz, op. cit., s. 21; W. KozŁowsKi, op. cit., s. 271.

${ }^{21}$ CAW WBH, sygn. I.400.2899, J. KoвYŁeCKi, 3 Dywizja Strzelców..., k. 21. 
w praktyce przeciwnikowi użycie kawalerii. Na całej trasie przemarszu kolumna marszowa dywizji musiała być odpowiednio ugrupowana, co tak wyjaśnił ppłk J. Kobyłecki: „warunki terenowe i atmosferyczne sprzyjały z jednej strony dywizji, z drugiej zaś wymagały takiego podziału sił w kolumnie marszowej, który by pozwalał bez skomplikowanych ewolucji, utrudnionych warunkami terenowymi, uszykować się do stawienia oporu w razie niespodziewanych napadów band chłopskich i regularnych oddziałów bolszewickich"22. Było to niezwykle trudne, gdyż długość tej kolumny wynosiła niemal $7 \mathrm{~km}$. Problem rozwiązano w dość prosty sposób, dzieląc cały tabor na cztery części, które przydzielono do poszczególnych pułków. Ponadto kolumny taborowe przedzielone były maszerującymi pododdziałami piechoty i saniami z karabinami maszynowymi. Taki podział kolumny marszowej pozwalał, by zarówno cała dywizja, jak i poszczególne części jej kolumny mogły odeprzeć niespodziewany atak, bez konieczności przesuwania pododdziałów. Zamysł przegrupowania 3 DSP zwięźle określił w swych wspomnieniach por. Aleksander Żebrowski: „Przewodnią myślą gen. Iwaszkiewicza było niewdawanie się w akcję z poważniejszymi siłami nieprzyjaciela, lecz wymijanie ich"23.

Po kilkudniowych przygotowaniach i oczekiwaniu na przybycie Brygady Rezerwowej (jej pozostałości dotarły do Jelni wieczorem 9 lutego) dowódca 3 DSP zwołał rankiem 10 lutego naradę z dowódcami pułków, na której omówił szczegóły przegrupowania mającego rozpocząć się następnego dnia. Ponieważ nie można było zabrać ze sobą całości posiadanego zaopatrzenia - nadmiar żywności i karabinów Mosin (te celowo uszkodzono poprzez zniszczenie iglic) pozostawiono w Jelni. W noc poprzedzającą wymarsz (tj. z 10 na 11 lutego) dowódca dywizji nakazał również wysłać dwa dwuosobowe patrole (oficera z szeregowym), którzy przebrani w cywilne ubrania mieli udać się saniami z ukrytymi w sianie materiałami wybuchowymi celem zniszczenia torów na linii kolejowej Smoleńsk-Rosław, którą oddziały dywizji miały niebawem przekroczyć. Jeden patrol udał się na południe od stacji Poczynek, drugi zaś na północ od niej. Wysadzenie torów miało uniemożliwić bolszewikom szybkie przegrupowanie swych oddziałów, po wykryciu przemarszu polskiej dywizji w kierunku zachodnim $^{24}$.

\footnotetext{
${ }^{22}$ CAW WBH, sygn. I.400.2899, J. KoвY£ecki, 3 Dywizja Strzelców..., k. 22.

${ }^{23}$ CAW WBH, sygn. I.400.2227, Relacja por. A. Żebrowskiego z 1935 r., k. 3.

${ }^{24}$ CAW WBH, sygn. I.400.2899, J. KoвYŁECKI, 3 Dywizja Strzelców..., k. 23.
} 
Po zakończeniu niezbędnych przygotowań - o świcie 11 lutego rozpoczęła się kilkutygodniowa odyseja żołnierzy 3 DSP w warunkach srogiej rosyjskiej zimy. Mrozy dochodzity wówczas do $20^{\circ} \mathrm{C}$ poniżej zera, nocami zaś przekraczały nawet $-30^{\circ} \mathrm{C}$. Jednak nie tylko mróz był problemem - nie mniejszym okazały się obfite opady śniegu, powodujące zaspy na drogach, które utrudniały nie tylko przemieszczanie się sań, lecz także marsz żołnierzy muszących wręcz „przedzierać się" przez hałdy śniegu. Co prawda większość z nich posiadała zimowe mundury przystosowane do realiów rosyjskiej zimy, lecz kilkutygodniowy przemarsz był dla nich trudnym doświadczeniem. Rankiem 11 lutego, po wysłuchaniu mszy świętej - kolumna dywizji wyruszyła około godz. 8.00 z Jelni w kierunku zachodnim, do oddalonego o około $25 \mathrm{~km}$ Bałtutina. W straży przedniej maszerował 9 ps, za główną zaś kolumną marszową - kroczyli w straży tylnej żołnierze 12 ps. Pierwszy etap przegrupowania odbył się bez żadnych przeszkód, dzięki czemu wieczorem dotarto do Bałtutina. Dopiero tu doszło do pierwszej wymiany ognia z niewielkim pododdziałem bolszewickim obsadzającym wspomnianą miejscowość. Po krótkim starciu, oddziały polskie wkroczyły do niej, żołnierze spędzili tu noc rozlokowani w domach mieszkańców ${ }^{25}$.

Rankiem 12 lutego rozpoczął się drugi etap przegrupowania 3 DSP. Około godz. 7.00 jej kolumna ruszyła w stronę oddalonej o około $15 \mathrm{~km} \mathrm{~m}$. Strigino. Tym razem trasa prowadziła przez lekko pagórkowaty - lecz niemal całkowicie odkryty - teren. Nic dziwnego, że marsz polskich oddziałów został szybko zauważony przez bolszewików, którzy wysłali przeciw nim niewielki pododdział z dwoma armatami, aby ich ogniem powstrzymać dalsze przemieszczanie się kolumny polskiej dywizji. Na szczęście ostrzał okazał się niecelny, lecz aby zlikwidować zagrożenie dowódca dywizji wysłał jedną z kompanii, która zmusiła pododdział wroga do odwrotu. Dalszy marsz odbył się już spokojnie i około godz. 15.00 polskie oddziały dotarły do wsi Strigino, gdzie rozlokowały się na nocleg - ostatni przed przekroczeniem linii kolejowej Smoleńsk-Rosław, gdzie spodziewano się napotkać silniejsze oddziały bolszewickie ${ }^{26}$.

${ }^{25}$ CAW WBH, sygn. I.400.2228, Relacja por. Tadeusza Ozimka..., k. 2; CAW WBH, sygn. I.400.2899, J. КовүŁескі, 3 Dywizja Strzelców..., k. 23-24; H. BAGiński, Wojsko Polskie..., s. 247-248; IDEM, Bohaterski przemarsz..., s. 93; H. OrLeAŃsKi, N.J. HerTZ, op. cit., s. 22. Warto tu dodać, że według relacji por. Aleksandra Żebrowskiego (CAW WBH, sygn. I.400.2227, Relacja por. A. Żebrowskiego z 1935 r., k. 1) wymarsz 3 DSP z Jelni miał nastąpić dopiero 13 lutego.

${ }^{26}$ CAW WBH, sygn. I.400.2899, J. Koвyєecki, 3 Dywizja Strzelców..., k. 23-24; CAW WBH, sygn. I.400.2228, Relacja por. Tadeusza Ozimka..., k. 2-3; H. BAGiński, Wojsko Polskie..., s. 248. 
W myśl opracowanego jeszcze w Jelni planu przegrupowania 3 DSP w kierunku Bobrujska - jej oddziały miały przekroczyć wspomnianą linię kolejową w pobliżu stacji Poczynek, leżącej mniej więcej w połowie odcinka kolejowego między Smoleńskiem a Rosławiem. Aby ułatwić ten manewr, dowódca dywizji - jak wcześniej podano - wysłał przodem z Jelni dwa dwuosobowe patrole na północ i na południe od tej stacji kolejowej, które miały za zadanie ograniczyć możliwość szybkiej reakcji i przegrupowania przez bolszewików większych oddziałów przeciw polskiej dywizji. Jednak w trakcie pobytu w $\mathrm{m}$. Strigino gen. W. Iwaszkiewicz-Rudoszański otrzymał meldunek, że w rejonie stacji Poczynek gromadzą się znaczne siły bolszewickie - starcie z którymi mogło okazać się tragiczne dla słabego związku taktycznego, jakim wówczas była 3 DSP. W tej sytuacji generał postanowił zastosować fortel i zmylić wroga. W tym celu 13 lutego o godz. 5.00 szkoła podoficerska 10 ps (około 50 żołnierzy wyposażonych w 10 ciężkich karabinów maszynowych) otrzymała rozkaz pozorowania marszu całej dywizji w kierunku wspomnianej stacji kolejowej, by następnie związać siły bolszewickie walką. Niebawem, o godz. 6.00, główne zgrupowanie dywizji wyruszyło ze wsi Strigino w kierunku przystanku kolejowego Engelgardtowskaja, położonego około $7 \mathrm{~km}$ na południe od stacji Poczynek. W tym czasie szkoła podoficerska 10 ps przemieszczała się w kierunku oddalonej o około $15 \mathrm{~km}$ stacji kolejowej Poczynek. W połowie drogi, kolumna - po opuszczeniu wsi Radysnkowo - został ostrzelana przez patrol bolszewicki rozlokowany w m. Luczesa (ob. Luchesa), położonej około $5 \mathrm{~km}$ na wschód od stacji Poczynek. Żołnierze polscy natychmiast rozwinęli się w tyralierę i przy wsparciu karabinów maszynowych zmusili wroga do odwrotu, robiąc przy tym jak najwięcej hałasu, by bolszewicy uwierzyli, iż to właśnie tu zasadnicze siły polskiej dywizji chcą przekroczyć wspomnianą linię kolejową. Dzięki temu żołnierze 9 ps idącego na czele głównej kolumny dywizyjnej - opanowali bez przeszkód przystanek kolejowy Engelgardtowskaja, w rejonie którego około godz. 13.00 oddziały dywizji zaczęły przekraczać linię kolejową. O swoim błędzie nieprzyjaciel zorientował się dopiero około godz. 15.00, gdy niemal cała dywizja przekroczyła już tory kolejowe. Bolszewicy wysłali natychmiast ze stacji Poczynek parowóz z platformą, na której ustawiono armatę polową, celem ostrzelania polskich oddziałów. Po dotarciu do celu i oddaniu zaledwie kilku strzałów, ogień karabinów maszynowych osłonowego posterunku 9 ps zmusił parowóz do wycofania się, co pozwoliło już w spokoju dokończyć około godz. 16.00 przegrupowanie dywizji na zachodnią 
stronę linii kolejowej Smoleńsk-Rosław. Następnie przemieściła się ona do oddalonej o około $10 \mathrm{~km}$ wsi Szymanówka, gdzie żołnierze rozlokowali się na zasłużony odpoczynek ${ }^{27}$. Starcie to tak opisał por. T. Ozimek: „Łatwe przejście dywizji przez tor kolejowy możemy zawdzięczyć umiejętnej demonstracji, jaką przeprowadziła szkoła podoficerów 10-go pułku pod Poczynkiem, jak również pułkownikowi Jasińskiemu, który ogniem karabinów maszynowych zmusił do cofnięcia się cały pociąg bolszewicki z armatami. Pod Poczynkiem szkoła podoficerów 10-go pułku stoczyła regularną walkę z bolszewikami nie ponosząc żadnych strat. Po dokonanej demonstracji szkoła przybyła do Szymanówki"28. Warto tu dodać, iż w czasie walk w rejonie stacji Poczynek „odnalazł się” por. Edward Perkowicz, adiutant dowódcy 10 ps, wysłany kilka dni wcześniej przez dowódcę 3 DSP do dowództwa I Korpusu Polskiego z informacją o przegrupowywaniu się dywizji w kierunku Bobrujska. W przebraniu chłopskim zdołał wykonać zadanie, a następnie powrócić 13 lutego do przegrupowującej się dywizjii ${ }^{29}$.

Żołnierzom 3 DSP nie dane było jednak spędzić nocy w Szymanówce, gdyż z uwagi na stosunkowo niewielką odległość od sił bolszewickich zgrupowanych w rejonie stacji Poczynek, gen. W. Iwaszkiewicz-Rudoszański obawiał się niespodziewanego ataku z ich strony. Dlatego też - nie zważając na zmęczenie ludzi i koni - nakazał wyruszyć w środku nocy z 13 na 14 lutego w dalszy marsz do oddalonej o $20 \mathrm{~km}$ w kierunku południowo-zachodnim m. Chosławicze. Było to wielkie wyzwanie dla wycieńczonych trzydniowymi marszami żołnierzy, tym większe, iż teraz musieli przemieszczać się w nocnych ciemnościach, przy trzaskającym mrozie sięgającym dwudziestu kilku stopni poniżej zera. Po kilkugodzinnym marszu, słaniający się na nogach, polscy żołnierze dotarli do Chosławicz, gdzie dowódca dywizji zarządził dwudniowy odpoczynek, niezbędny dla nabrania sił. Oficerów rozlokowano w domach mieszkańców, szeregowych zaś i podoficerów w stodołach i szopach dających możliwość schronienia przed mrozem. Pobyt oddziałów dywizji w m. Chosławicze przebiegł spokojnie, choć 15 lutego patrol konnych wywiadowców doniósł, że bolszewicy spodziewający się dalszego marszu 3 DSP główną drogą w kierunku Mścisławia, skoncentrowali w jego

27 CAW WBH, sygn. I.400.2899, J. KobyŁecki, 3 Dywizja Strzelców..., k. 24-26; H. BAgiŃSKI, Wojsko Polskie..., s. 248-249; IDEM, Bohaterski przemarsz..., s. 93.

${ }^{28}$ CAW WBH, sygn. I.400.2228, Relacja por. Tadeusza Ozimka..., k. 3.

${ }^{29}$ H. BAGIŃsKI, Bohaterski przemarsz..., s. 94. 
rejonie znaczne siły (zarówno jazdy, jak i piechoty). Z kolei wieczorem inny patrol poinformował, że z północy (od strony Smoleńska) zbliża się pułk kawalerii, który w otwartym terenie - na jakim kwaterowała dywizja - mógłby stanowić poważne zagrożenie. Dodatkowo zachodziły obawy, iż na odgłos walki z kawalerią - mogłyby pospieszyć jej z pomocą bolszewickie oddziały z kierunku zachodniego (od strony Mścisławia) oraz z kierunku wschodniego (od strony Rosławia). W tej sytuacji gen. W. Iwaszkiewicz-Rudoszański zdecydował się przerwać odpoczynek dywizji i opuścić zagrożony rejon, w którym bolszewicy mogliby w krótkim czasie wziąć polską jednostkę w kleszcze i zmusić ją do kapitulacji ${ }^{30}$.

Po zakończeniu niezbędnych prac przygotowawczych, o zmroku 15 lutego oddziały 3 DSP wyruszyły - po raz kolejny nocą - na południe, w kierunku oddalonej o około $25 \mathrm{~km} \mathrm{~m}$. Piotrowicze. Jednak w nocnych ciemnościach dogonił je pododdział piechoty bolszewickiej poruszający się saniami. Doszło do gwałtownego starcia, zakończonego odwrotem wroga, co strona polska okupiła niewielkimi stratami (rannych zostało pięciu żołnierzy oraz utracono jeden karabin maszynowy). Poza tą potyczką dalszy marsz kolumny dywizyjnej przebiegł spokojnie, dzięki czemu zmęczeni i przemarznięci żołnierze dotarli 16 lutego (około godz. 10.00) do Piotrowicz. Tu dowódca dywizji zarządził jedynie kilkugodzinny odpoczynek, gdyż obawiał się kolejnego ataku sił bolszewickich z kierunku Rosławia, odległego o niecałe $50 \mathrm{~km}$. Dlatego też kolumna dywizji w godzinach popołudniowych wyruszyła w dalszy marsz w kierunku Studzieniec (leżących około $15 \mathrm{~km}$ na południowy zachód), do których dotarła wieczorem, gdzie też jej żołnierze rozlokowali się na nocleg ${ }^{31}$.

Rankiem 17 lutego oddziały dywizji ruszyły w silnym mrozie w dalszą drogę $\mathrm{w}$ kierunku położonego około $30 \mathrm{~km}$ na południe miasteczka Klimowicze nad rzeką Łobzanką, gdzie dotarły późnym wieczorem. Na wieść o zbliżaniu się polskich oddziałów, lokalne władze bolszewickie uciekły w popłochu, grupa zaś mieszkających tu Polaków entuzjastycznie powitała polskich żołnierzy. „Ludność miasta spotkała nas chlebem i solą. Z więzienia uwolniono obywateli Polaków, 1 oficera i żołnierza, z 1 Dywizji, których bolszewicy nie zdążyli rozstrzelać"32. W miasteczku żołnierze spędzili nie tylko najbliższą noc, ale również

${ }^{30}$ CAW WBH, sygn. I.400.2899, J. Koвy£ecki, 3 Dywizja Strzelców..., k. 27; H. BAGiński, Wojsko Polskie..., s. 249; IDEM, Bohaterski przemarsz..., s. 94.

31 CAW WBH, sygn. I.400.2899, J. КовүŁecki, 3 Dywizja Strzelców..., k. 28; H. BAGiński, Wojsko Polskie..., s. 250.

32 CAW WBH, sygn. I.400.2228, Relacja por. Tadeusza Ozimka..., k. 4. 
cały kolejny dzień (18 lutego), goszczeni przez polskich mieszkańców, którzy tego dnia urządzili dla żołnierzy zabawę taneczną. Klimowicze oddziały polskie opuściły rankiem 19 lutego, rozpoczynając kolejne przegrupowanie w rejon oddalonej o około $20 \mathrm{~km}$ wsi Borysowicze ${ }^{33}$.

Droga była niemal całkowicie zaśnieżona, a trzaskający mróz znacznie spowolnił tempo marszu. Wieczorem kolumna dywizji dotarła do celu, gdzie żołnierze spędzili noc w wiejskich chatach, stodołach i szopach. Rankiem 20 lutego - przy siarczystym mrozie - dywizja ruszyła do oddalonej o prawie $40 \mathrm{~km}$ wsi Bakunowicze, leżącej w pobliżu rzeki Soż. Niemal cała droga tego dnia prowadziła duktami leśnymi, zasypanymi obficie śniegiem. Pomimo tych trudności i postępującego zmęczenia - wieczorem kolumna dywizji dotarła do celu. „Całodzienny przemarsz, przy mrozie dochodzącym do dwudziestu kilku stopni, drogi zawiane głębokim śniegiem, wreszcie niedostateczne odżywianie podczas ostatnich przemarszów, wszystko to wyczerpało znacznie siły ludzi i koni. Poza tym ciągła obawa napadów ze strony uzbrojonych i wrogo usposobionych wobec dywizji band chłopskich, które jak szakale śledziły każdy ruch dywizji i szukały sposobności do napadu i zrabowania zapasów żywności, które posiadała dywizja, trzymała dywizję w ciągłym napięciu i denerwowała żołnierzy. Mimo to nastrój żołnierzy był dobry i wśród nich panowała doskonała dyscyplina oraz zaufanie dla Dowódcy dywizji Generała Iwaszkiewicza, którego niezmordowana energia, odwaga i pewność siebie, działały imponująco na podwładnych i trzymała ich w rygorze i posłuszeństwie" ${ }^{34}$.

Po nocy spędzonej w Bakunowiczach, rankiem 21 lutego dywizja podjęła dalszy marsz, tym razem znacznie krótszy, gdyż „tylko” około 20-kilometrowy. Jednak teraz kolumna dywizji - oprócz śniegu i mrozu - musiała pokonać jeszcze jedną przeszkodę, jaką była rzeka Soż, którą przekroczono po lodzie. Na jej lewym brzegu dywizja zatrzymała się na noc w m. Gajszyn (obecnie Hajsyn), skąd rankiem 22 lutego wyruszyła w dalszą drogę - do oddalonej o prawie $30 \mathrm{~km}$ wsi Korma. Tu żołnierze mogli nieco odpocząć, gdyż gen. W. Iwaszkiewicz-Rudoszański zarządził dłuższy postój, celem pozyskania informacji o sytuacji i rozpoznania dalszego kierunku marszu w stronę Bobrujska. Zwiadowcy szybko poinformowali, że rejon Rohaczewa i Żłobina jest obsadzony przez regularne oddziały Armii Czerwonej, na południu zaś oddziały niemieckie posuwają

\footnotetext{
${ }^{33}$ H. Bagiński, Wojsko Polskie..., s. 250; H. Orleański, N.J. Hertz, op. cit., s. 23.

${ }^{34}$ CAW WBH, sygn. I.400.2899, J. КовYєескі, 3 Dywizja Strzelców..., k. 29.
} 
się w kierunku wschodnim, w stronę Homla. Dowódca dywizji musiał podjąć decyzję o kierunku dalszego marszu, mając do wyboru alternatywę: ruszyć nieco dłuższą trasą na południe i nawiązać kontakt z Niemcami, by pod ich osłoną przedostać się w rejon Bobrujska albo kontynuować marsz na zachód i po przekroczeniu Dniepru pomiędzy Rohaczewem a Żłobinem siłą przebić się przez oddziały bolszewickie, by najkrótszą drogą dotrzeć w okolice Bobrujska. Nie mając jednak pewności, jaki byłby stosunek Niemców do dywizji, gen. W. Iwaszkiewicz-Rudoszański wybrał ostatecznie drugi wariant. Był on co prawda bardziej niebezpieczny, gdyż wymagał pokonania oddziałów bolszewickich przegradzających najkrótszą drogę ku I Korpusowi Polskiemu - dawał jednak w przypadku sprawnego przeprowadzenia tego manewru gwarancję szybkiego dotarcia w rejon Bobrujska. O podjętej decyzji sztab korpusu miał poinformować - wspomniany wcześniej - por. E. Perkowicz, który z tą misją wyruszył w drogę 23 lutego 35 .

Po jednodniowym odpoczynku, oddziały 3 DSP podjęły rankiem 24 lutego dalszy marsz w kierunku oddalonego o niemal $40 \mathrm{~km}$ miasteczka Gorodziec, gdzie przybyły pod wieczór. Sztab dywizji wraz z 10 i 12 ps rozlokował się w miasteczku, 11 ps w jego okolicy, 9 ps zaś osłaniał zgrupowanie dywizji przed niespodziewanym atakiem wroga. Rankiem 25 lutego 10 i 12 ps ruszyły przodem w kierunku zachodnim. W tym czasie nadeszła do dowództwa dywizji wiadomość, iż 11 ps został zaatakowany przez oddział bolszewicki i odcięty. Niebawem ten sam oddział zaatakował miejsce postoju dywizji w miasteczku Gorodziec. Generał W. Iwaszkiewicz-Rudoszański rzucił do walki kompanię sztabową, która związała walką nieprzyjacielski oddział na przedmieściach miasteczka, co wykorzystał 11 ps, który w tym czasie po krótkiej walce utorował sobie drogę do $\mathrm{m}$. Gorodziec. W tym czasie z pomocą przyszedł 9 ps znajdujący się dotąd w straży tylnej. Jego pojawienie się na polu walki zmusiło wroga do odwrotu. Po krótkim odpoczynku, oba pułki wraz z dowództwem dywizji podjęły marsz za 10 i 12 ps, które siłą torowały drogę dywizji ${ }^{36}$.

W następnych godzinach (25 lutego) oddziały dywizji, maszerując w siarczystym mrozie i tocząc potyczki z pododdziałami wroga, zdołały wieczorem

35 CAW WBH, sygn. I.400.2899, J. KовүŁескі, 3 Dywizja Strzelców..., k. 30; H. Bagiński, Wojsko Polskie..., s. 251; IDEM, Bohaterski przemarsz..., s. 95.

36 CAW WBH, sygn. I.400.2899, J. KoвyєECKi, 3 Dywizja Strzelców..., k. 30-31; CAW WBH, sygn. I.400.2228, Relacja por. Tadeusza Ozimka..., k. 5. 
dotrzeć do skutej lodem rzeki Dniepr, którą zaczęły przekraczać w godzinach nocnych. Najpierw na zachodni brzeg przedostała się po lodzie straż przednia, która obsadziła leżącą tuż za rzeką wieś Luczyn, osłaniając przejście sił głównych. W miejscowości tej - zaskoczywszy wroga - żołnierze straży przedniej zdobyli nieprzyjacielską baterię wraz z jaszczami amunicyjnymi. Zażegnawszy potencjalne zagrożenie ze strony artylerii bolszewickiej, główna kolumna 3 DSP przeszła spokojnie po lodzie na zachodni brzeg Dniepru, skąd skierowała się w kierunku wsi Zabłocie, położonej $7 \mathrm{~km}$ od Luczyna. Wysłany przodem patrol konnych wywiadowców doniósł, iż stacjonował tam bolszewicki 19 Pułk Strzelców Syberyjskich. Poinformowany o tym dowódca 10 ps - idącego w straży przedniej - nakazał rozmieścić wszystkie znajdujące się na wyposażeniu pułku karabiny maszynowe na stanowiskach bojowych, by w zasięgu ich ostrzału znalazła się cała wieś. Niebawem przybył tu dowódca dywizji, który rozkazał przyprowadzić jednego ze schwytanych jeńców. Odesłano go, by przekazał swemu dowódcy, iż wieś jest otoczona przez Polaków. Dowódca bolszewickiego pułku płk Firsow (imienia nie ustalono) zaprosił dowódcę 3 DSP do swego sztabu na rozmowy. Generał W. Iwaszkiewicz-Rudoszański - pomimo grożącego niebezpieczeństwa - udał się na nie. W ich trakcie okazało się, iż większość żołnierzy wroga pochodzi z Syberii i marzy tylko o powrocie do swych domów, nie chcąc brać dalszego udziału w walkach. Nic dziwnego, że w tej sytuacji szybko osiągnięto porozumienie. Dowódca 19 Pułku Strzelców Syberyjskich obiecał, że podległe mu pododdziały pozwolą polskiej dywizji spokojnie przejść przez miejscowość. Po tym bezkrwawym zwycięstwie osiągniętym dzięki umiejętnym pertraktacjom dowódcy 3 DSP, polskie oddziały - wykorzystując panujące jeszcze ciemności - ruszyły dalej w kierunku zachodnim, zmierzając w stronę oddalonej o $10 \mathrm{~km}$ wsi Pobołów ${ }^{37}$.

Jako pierwszy dotarł w jej okolice - około godz. 2.00 dnia 26 lutego - idący w straży przedniej 10 ps, którego żołnierze zajęli pozycje ogniowe czekając na rozkaz ataku. W tym czasie wzięto do niewoli dwóch żołnierzy wroga, którzy wyjawili, że we wsi stacjonuje batalion marynarzy dysponujący wieloma karabinami maszynowi, dwoma armatami oraz dwoma samochodami pancernymi, a $10 \mathrm{~km}$ dalej na północ była rozlokowana cała dywizja bolszewicka. Sytuacja

${ }^{37}$ CAW WBH, sygn. I.400.2899, J. KoвyŁecki, 3 Dywizja Strzelców..., k. 32-34; CAW WBH, sygn. I.400.2228, Relacja por. Tadeusza Ozimka..., k. 5-6; H. BAgIŃski, Wojsko Polskie..., s. 252-253; IDEM, Bohaterski przemarsz..., s. 95. 
stała się trudna, toteż żołnierze polscy musieli działać energicznie, by siłą przełamać ostatnią przeszkodę odgradzającą ich od I Korpusu Polskiego. Musiano to uczynić szybko, by do walki nie zdążyły włączyć się posiłki bolszewickie ze stojącej niedaleko nieprzyjacielskiej dywizji. Na skraju lasu rozlokowano na stanowiskach ogniowych 20 ciężkich karabinów maszynowych, które rozpoczęły intensywny ostrzał pozycji wroga. Niedługo potem do szturmu ruszyli żołnierze 10 ps (9 i 11 ps pozostały w odwodzie, 12 ps zaś osłaniał dywizję od północy). Natarcie polskich żołnierzy napotkało jednak twardy opór, toteż dowódca dywizji wsparł je pododdziałami 9 ps, lecz i to nie przyniosło zamierzonego efektu. W konsekwencji gen. W. Iwaszkiewicz-Rudoszański około godz. 5.00 rzucił do walki swój ostatni odwód w postaci 11 ps. Sytuacja stawała się krytyczna, gdyż pomimo skierowania do walki niemal całej dywizji nie przełamano oporu wroga, a przedłużające się starcie i zbliżający się świt rodziły obawy, iż niebawem nadciągną na plac boju posiłki ze stacjonującej niedaleko dywizji bolszewickiej. Po uporządkowaniu własnych szeregów - tuż przed świtem - wznowiono natarcie. Tym razem dało ono efekt i po półgodzinnym intensywnym starciu złamano opór wroga, wdzierając się do wsi. Broniący jej batalion marynarzy uległ rozproszeniu, do polskiej zaś niewoli dostało się około 100 jego żołnierzy - Polacy zdobyli także dwa uszkodzone samochody pancerne. Od mieszkańców zajętej miejscowości dowiedziano się, że zaledwie kilka kilometrów na zachód od Pobołowa znajdują się wysunięte pododdziały I Korpusu Polskiego. W tej sytuacji, obawiając się odwetowego ataku ze strony sił bolszewickich - dowódca 3 DSP nakazał jak najszybciej uporządkować szeregi dywizji, by następnie ruszyć w kierunku zachodnim. Pomimo ogromnego zmęczenia, polscy żołnierze z werwą podjęli ostatni wysiłek maszerując w śnieżnej zawiei, która uniemożliwiła bolszewikom obserwację polskiego manewru. Dzięki temu - bez przeciwdziałania ze strony wroga - w godzinach popołudniowych 26 lutego oddziały polskiej dywizji dotarły do wsi Turka, gdzie napotkały żołnierzy 3 Pułku Ułanów. Doszło do entuzjastycznego powitania i wybuchu radości, iż odyseja dywizji dobiegła końca ${ }^{38}$.

${ }^{38}$ CAW WBH, sygn. I.400.2899, J. KoвYŁecki, 3 Dywizja Strzelców..., k. 35-38; CAW WBH, sygn. I.400.2228, Relacja por. Tadeusza Ozimka..., k. 6-7; CAW WBH, sygn. I.400.2231, Relacja kpt. Bronisława Bednarczyka o walkach pod Pobojowem, k. 2-6; H. BAGIŃski, Wojsko Polskie..., s. 254-255; IDEM, Bohaterski przemarsz..., s. 95-96; H. ORLEAŃSKI, N.J. HERTZ, op. cit., s. 23-24; J. Dowbor Muśnicki, Krótki szkic do historii I-go Polskiego Korpusu, cz. 2, Warszawa 1919, s. 22. 
W rejonie wspomnianej wsi 3 DSP rozlokowała się na kilka dni, by uporządkować szeregi i zapewnić wycieńczonym żołnierzom niezbędny odpoczynek. Następnym etapem był przemarsz w okolice Bobrujska, gdzie oddziały I Korpusu Polskiego prowadziły ciężkie walki, by odzyskać kontrolę nad ważną linią kolejową Żłobin-Rogaczew oraz wyprzeć siły bolszewickie na wschodni brzeg Dniestru. Biorąca udział w tych walkach 3 DSP zajęła w pierwszych dniach marca rejon Żłobin. Tu otrzymała zadanie obrony odcinka frontu Korpusu opartego o linię rzeki Dniestr, od ujścia rzeki Berezyny do Rogaczewa. W rejonie Żłobina oddziały dywizji pozostawały do czasu rozbrojenia I Korpusu Polskiego przez Niemców w maju 1918 r. ${ }^{39}$

Trudno ocenić starty, jakie 3 DSP poniosła w trakcie lutowego przemarszu. Jak wcześniej podano, wyruszając z Jelni liczyła ona (wraz z pozostałościami 8 ps i Brygady Rezerwowej) około 3400 żołnierzy ${ }^{40}$. Według Mieczysława Wrzoska - po przybyciu w rejon Żłobina jej liczebność wynosiła około 2500 ludzi ${ }^{41}$, co oznaczało, iż jej stan zmalał o około 900 żołnierzy, czyli niemal o 30\%. Według raportów poszczególnych pułków 3 DSP - sporządzonych na początku marca - w trakcie przemarszu ich straty bojowe były niewielkie: kompania sztabowa dywizji - 3 zabitych i 9 rannych, 8 ps -2 zabitych, 9 ps - 1 zabity i 4 rannych, 10 ps -5 zabitych i 7 rannych, 11 ps -9 rannych oraz 12 ps -3 rannych $^{42}$. Wysokość strat wydaje się zdecydowanie za mała, biorąc pod uwagę liczne walki stoczone przez żołnierzy 3 DSP w trakcie przemarszu, zwłaszcza w bitwie pod Pobołowem. Jednak wspomniany wykaz dotyczy żołnierzy poległych i rannych znanych z imienia i nazwiska, toteż zapewne nie uwzględnia on żołnierzy o nieznanych personaliach. Dodatkowo trzeba pamiętać, iż oprócz bezpośrednich strat bojowych dywizja musiała niewątpliwie ponieść także duże tzw. straty marszowe - spowodowane przykładowo

39 CAW WBH, Dowództwo I Korpusu Polskiego w Rosji, sygn. I.122.1.144, Rozlokowanie oddziałów 3 DSP w rejonie Żłobina w marcu 1918 r., brak paginy; W. LIPIŃski, op. cit., s. 260-261 i 282-283; H. BAgiński, Wojsko Polskie..., s. 256; M. Wrzosex, Wojskowość polska podczas..., s. 197.

40 CAW WBH, sygn. I.400.2899, J. Koвү£ескI, 3 Dywizja Strzelców..., k. 23; CAW WBH, sygn. I.400.2228; Relacja por. Tadeusza Ozimka..., k. 1-2.

41 M. Wrzosek, Polskie korpusy wojskowe..., s. 213.

42 CAW WBH, 3 DSP, sygn. I.122.18.5, Lista oficerów i żołnierzy 3 DSP zabitych i rannych w walkach z bolszewikami w trakcie przemarszu z Jelni do Żłobina z początku marca 1918 r., brak paginy. 
chorobami, odmrożeniem oraz zagubieniem się części żołnierzy w trakcie przemarszu przez nieznany im teren. Jeśli to wszystko uwzględnimy, to straty sięgające niemal 900 ludzi będzie znacznie łatwiej wytłumaczyć, ich zaś wysokość z uwagi na ówczesne warunki pogodowo-terenowe staje się bardziej realna.

Przemarsz dywizji przeszedł do historii polskiego oręża. Skalę trudności słynnego przemarszu dobrze oddają wspomnienia por. A. Żebrowskiego, w których ukazana została gehenna polskich żołnierzy: „Nadmienić należy, że marsz odbywał się ziemiami zamieszkałymi przez ludność zbolszewizowaną, a tym samym wrogo do nas usposobioną. W większości wypadków ludność prowokowana i straszona przez nieprzyjaciela opuszczała swoje siedziby pozostawiając je na łasce losu, nam zaś starała się wszelkimi sposobami dokuczać, strzelając z ukrycia w maszerujące oddziały, które nie mogły przedsięwziąć energicznych agresywnych środków represyjnych, gdyż dywizja przebywała około 30 wiorst na dobę, brodząc w śniegu do pasa przy dotkliwym mrozie w miejscowościach bez dróg, i wszelkie oddalenie się poszczególnych oddziałów w celu odpędzenia ostrzeliwującej nas ludności, groziło tymże oddziałom pozostawienie na łasce losu lub zmarznięcie w śniegu. W takich warunkach dywizja posuwała się przez szereg dni, jednakże potyczki jakie odbywały się przez te dni nie przyczyniły

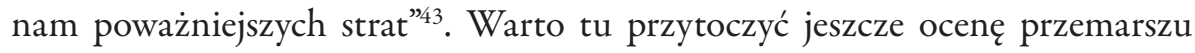
3 DSP zawartą we wspomnieniach por. T. Ozimka: „Dzieje przemarszu 3 Dywizji Strzelców z Jelni do rejonu Żłobina, przejdą do historii Wojska Polskiego, jako jedna z najpiękniejszych kart dziejów I-go Korpusu Polskiego. Zawdzięczać to należy wielkiemu hartowi i odwadze naszego oficera i żołnierza, na czele którego stał ś.p. generał Wacław Iwaszkiewicz, który był zawsze pierwszym w boju, a ostatnim w spoczynku”4. Wielką rolę dowódcy dywizji w przeprowadzeniu dywizji z Jelni do Żłobina podkreślali praktycznie wszyscy jej żołnierze, jak również Henryk Bagiński w swej monografii poświęconej dziejom Wojska Polskiego w Rosji w latach I wojny światowej: „Zawdzięczać to należy wielkiemu hartowi i odwadze naszych piechurów, na czele których stał gen. Iwaszkiewicz. Sam dawał przykład, idąc całą drogę pieszo, prawie w letnim szyneliku, podpierając się laską. Jego oczom nic nie uszło, a dla oficerów i wyższych dowódców był nadzwyczaj surowy za najmniejszą niedbałość w wykonaniu rozkazu. Dlatego żołnierze z ufnością spoglądali na swego generała. Na posiedzeniu pierwszym

\footnotetext{
${ }^{43}$ CAW WBH, sygn. I.400.2227, Relacja por. A. Żebrowskiego z 1935 r., k. 3.

${ }^{44}$ CAW WBH, sygn. I.400.2228, Relacja por. Tadeusza Ozimka..., k. 7.
} 
w Jelni, oświadczył że sam jeden pójdzie do Bobrujska, zginie lub dojdzie i jego stanowczej, żelaznej woli, bezgranicznej odwadze i wytrwałości, trzecia dywizja

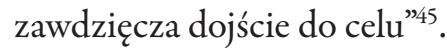

W uznaniu zasług za sprawne przeprowadzenie w lutym 1918 r. 3 DSP z Jelni do Bobrujska - gen. W. Iwaszkiewicz-Rudoszański otrzymał w 1922 r. Order Virtuti Militari II klasy ${ }^{46}$, co gen. J. Dowbor Muśnicki, dawny dowódca I Korpusu Polskiego w Rosji, tak uzasadniał: „Gen. Iwaszkiewicz był zupełnie odcięty od reszty sił korpusu. 3-a Dywizja, którą dowodził, mogła się złączyć z resztą oddziałów tylko przedzierając się przez masy bolszewickich wojsk, które otaczały dywizję. Otrzymawszy rozkaz wyruszyć pod Bobrujsk, gen. Iwaszkiewicz przystąpił do wykonania tego zalecenia, wierząc w siłę swoich żołnierzy i mając za moralną postawę tylko konieczność spełnienia mojego rozkazu. Trzykrotnie, 3-a Dywizja mając na czele gen. Iwaszkiewicza przebiła się na lewym brzegu Dniepru przez mur bolszewików; przeszedłszy zaś na prawy brzeg Dniepru, w bitwie pod Pobołowem gen. Iwaszkiewicz rozbił bolszewików i przyłączył się do korpusu. Marsz wykonany przez gen. Iwaszkiewicza, około $600 \mathrm{~km}$ [odległość znacznie zawyżona - W. J.] zimową porą wśród zimna i bezdroża, marsz utrudzony koniecznością przeprowadzić olbrzymi tabor i jednocześnie przebijać się siłą oręża przez bolszewików, może służyć wyjątkowym przykładem nie tylko w historii Polski, ale i w historii wojskowości całego świata"7 . Za wspomniany wyczyn, kilka miesięcy przed swoją śmiercią, gen. W. Iwaszkiewicz-Rudoszański otrzymał także, w kwietniu 1922 r., Krzyż Walecznych (nr 46165), umotywowany również przez gen. J. Dowbora Muśnickiego: „Dzięki energii i męstwu

${ }^{45}$ H. BAGiŃski, Wojsko Polskie..., s. 256.

46 „Dziennik Personalny Ministerstwa Spraw Wojskowych” 1922, nr 55, s. 908. Jednak według G. Łunomskiego (Kawalerowie Virtuti Militari 1792-1945. Stownik biograficzny, t. 2: 1914-1921, cz. 1 (zeszyt próbny), Koszalin 1991, s. 54) miał otrzymać Order Virtuti Militari V klasy o numerze 3, lecz w aktach personalnych gen. W. Iwaszkiewicza-Rudoszańskiego - jest informacja w Karcie kwalifikacyjnej z 1921 r., iż był odznaczony tylko Orderem Virtuti Militari II klasy (CAW WBH, ap. W. Iwaszkiewicz-Rudoszański, sygn. I.480.11, Wniosek o nadanie Orderu Virtuti Militari z 18 IX 1921 r., k. 46). Z kolei M. ZGórniak (Iwaszkiewicz-Rudoszański Wactaw, [w:] Polski Stownik Biograficzny, t. 10, Wrocław 1962-1964, s. 185) podał bez bliższych szczegółów, iż gen. W. Iwaszkiewicz-Rudoszański był dwukrotnie odznaczony Orderem Virtuti Militari II i V klasy - jednak w jego aktach personalnych zachowany jest tylko jeden wniosek o nadanie mu Orderu Virtuti Militari, choć w jednym z dokumentów jest informacja, iż był odznaczony dwoma Orderami (II i V klasy), lecz bez podania bliższych danych na ten temat.

${ }^{47}$ CAW WBH, ap. W. Iwaszkiewicz-Rudoszański, sygn. I.480.11, Wniosek o nadanie Orderu Virtuti Militari z 18 IX 1921 r., k. 46. 
jenerała-podporucznika Iwaszkiewicza, który szedł zawsze na czele żołnierzy, dywizja przeszła się przez bandy bolszewickie do Bobrujska zabrawszy opancerzony automobil i kulomioty" ${ }^{\prime 48}$. W marcu 1933 r. W. Iwaszkiewicz-Rudoszański otrzymał - tym razem pośmiertnie - Krzyż Niepodległości, co tak uzasadniono: „W październiku 1917 r. [winno być w listopadzie - W.J.] obejmuje dowództwo 3 Dywizji Strzelców Polskich. Przystępuje do energicznej pracy nad zorganizowaniem dywizji i spojeniem korpusu oficerskiego i dzięki czemu stworzył z dywizji najbardziej zdyscyplinowaną i zdolną do walki jednostkę w I Korpusie. Dzięki jego osobistym zaletom, jako dowódcy 3 Dywizja dokonała słynnego przemarszu z Jelni do Bobrujska wśród stałych [starć] z przeważającymi siłami bolszewickimi [...]. W czasie tych walk osobistym przykładem męstwa i troską o żołnierza podnosił ducha dywizji”49. Przyznanie gen. W. Iwaszkiewiczowi-Rudoszańskiemu tych wysokich odznaczeń było docenieniem jego wielkiego wysiłku dla ocalenia nie tylko samej dywizji, lecz przede wszystkim jej żołnierzy, co tak podsumował w swych wspomnieniach gen. J. Dowbor Muśnicki: „Jen. Iwaszkiewicz wyjątkowo zasłużył się Polsce. Ludzie mniejszych, a czasem wątpliwych zasług, zostali uczczeni wkrótce po śmierci. A takiej miary bohater, jak jenerał Iwaszkiewicz, doczekał się tylko skromnego pomnika na cmentarzu we Lwowie" ${ }^{\text {50 }}$.

Warto jeszcze dodać, iż dowódca 3 DSP wykazał się pięknym gestem wobec uczestniczących w marszu kilkuset żołnierzy 8 ps i Brygady Rezerwowej, którym podziękował za wysiłek i heroizm w specjalnym rozkazie wydanym 1 marca 1918 r.: „Przeszło dwa tygodnie [...] 3-ia Polska Dywizja przeżywała ciężkie chwile z powodu przemarszu z Jelni do Bobrujska. Chwile te dzielili z 3-ią dywizją i ludzie Rezerwowej Brygady i 8-go pułku, przeżywając razem wszystkie trudy i niewygody tego przemarszu i dzielnie walcząc bok o bok z 3-ią dywizją. Sławę, którą zdobyła sobie 3-ia dywizja w znacznej części zawdzięcza ona pomocy Rezerwowej Brygady i 8-go pułku. W imieniu Ojczyzny serdecznie dziękuję wszystkim oficerom i żołnierzom Rezerwowej Brygady i 8-go pułku za wspólną bojową pracę i żałując że tak krótko dowodziłem Wami, bohatery

${ }^{48}$ CAW WBH, ap. W. Iwaszkiewicz-Rudoszański, sygn. I.480.11, Wniosek o nadanie Krzyża Walecznych z 19 IV 1922 r., CAW WBH, ap. W. Iwaszkiewicz-Rudoszański, Wniosek o nadanie Krzyża Niepodległości z 16 III 1933 r., k. 48.

49 CAW WBH, ap. W. Iwaszkiewicz-Rudoszański, sygn. I.480.11, k. 52.

50 J. Dowbor Muśnicki, Moje wspomnienia, Poznań 1936, s. 106. 
życzę wam na przyszłość także dzielnie stawać w obronie Ojczyzny" ${ }^{\prime 1}$. Nie należy też zapomnieć o ks. Antonim Niewiarowskim, który będąc kapelanem 3 DSP przez cały czas przemarszu dywizji dodawał żołnierzom otuchy w trudnych chwilach ${ }^{52}$.

Podsumowując należy stwierdzić, iż przemarsz 3 DSP z Jelni do Żłobina był wyjątkowy w historii Wojska Polskiego. Odbywał się w niezmiernie trudnych warunkach pogodowych - poprzez zaspy śnieżne i przy mrozie dochodzącym nocami do $-30^{\circ} \mathrm{C}$. Nie tylko aura i teren były przeszkodami dla polskich żołnierzy, lecz również narastające z każdym dniem przemarszu trudności $\mathrm{w}$ wyżywieniu (nieregularne posiłki) ${ }^{53}$. Przegrupowanie odbywało się w stałej styczności z oddziałami bolszewickimi, które usiłowały nie dopuścić do połączenia się polskiej dywizji z głównymi siłami Korpusu, toteż jej żołnierze musieli stoczyć z wrogiem szereg potyczek i większych starć, w tym największy i najkrwawszy bój pod Pobołowem. Trzeba tu dodać, że przemarsz dywizji był także przekładem dobrze przemyślanej taktyki dostosowywanej na bieżąco przez jej dowódcę do zmieniającej się sytuacji i warunków terenowo-pogodowych. W ciągu niemal trzech tygodni żołnierze 3 DSP przeszli ponad $400 \mathrm{~km}$, docierając ostatecznie pod koniec lutego w rejon Żłobina, gdzie połączyli się z I Korpusem Polskim w Rosji - kończąc swą epopeję będącą dowodem wielkiego poświęcenia żołnierza polskiego dla Ojczyzny.

\section{BIBLIOGRAFIA}

\section{Źródła archiwalne}

Centralne Archiwum Wojskowe (Wojskowe Biuro Historyczne)

Akta personalne: Wacław Iwaszkiewicz-Rudoszański, sygn. I.480.11; Adolf Kuczewski, sygn. I.480.301; Julian Kobyłecki, sygn. I.480.261; Albin Jasiński, sygn. I.480.223; Leon Silicki, sygn. 7662; Józef Kopytyński, sygn. 5386; Wacław Krupowicz, sygn. 19497.

${ }^{51}$ Rozkaz dowódcy 3 DSP z 1 III 1918 r., CAW WBH, 3 DSP, sygn. I.122.18.14, brak paginy.

52 Świadectwo służby ks. A. Niewiarowskiego w szeregach 3 DSP z maja 1918 r., CAW WBH, 3 DSP, sygn. I.122.18.21, brak paginy.

${ }_{53}$ Meldunki pułków 3 DSP do intendenta dywizji z lutego i marca 1918 r., CAW WBH, 3 DSP, sygn. I.122.18.41, brak paginy. 
Dowództwo I Korpusu Polskiego w Rosji, sygn. I.122.1.144.

Dowództwo 3 DSP, sygn. I.122.18.5, I.122.18.14, I.122.18.21, I.122.18.41.

Dowództwo 9 ps, sygn. I.122.32.40.

Dowództwo 10 ps, sygn. I.122.33.41.

Rękopisy i wspomnienia, sygn. I.400.2899, I.400.2227, I.400.2228, I.400.2231.

\section{Źródła drukowane}

„Dziennik Personalny Ministerstwa Spraw Wojskowych” 1922, nr 55.

\section{Opracowania}

Bagiński H., Bohaterski przemarsz III Dywizji z Jelni do Bobrujska, „Wiadomości Wojskowe" 1918, nr 7-8, s. 92-97.

Bagiński H., Wojsko Polskie na Wschodzie 1914-1920, Warszawa 1921.

Dowbor Muśnicki J., Krótki szkic do historii I-go Polskiego Korpusu, cz. 2, Warszawa 1919.

Dowbor Muśnicki J., Moje wspomnienia, Poznań 1936.

Jarno W., Generat Wactaw Iwaszkiewicz-Rudoszański (1871-1922) - zarys biografii, „Acta Universitatis Lodziensis", Folia Historica 104, 2019, s. 125-146.

Kozłowski W., Artyleria polskich formacji wojskowych podczas I wojny światowej, Łódź 1993.

Lipiński W., Walka zbrojna o niepodlegtość Polski w latach 1905-1918, Warszawa 1990.

Łukomski G., Kawalerowie Virtuti Militari 1792-1945. Stownik biograficzny, t. 2: 1914-1921, cz. 1 (zeszyt próbny), Koszalin 1991.

Orleański H., Hertz N.J., I Korpus Polski. Rys historyczny, Warszawa 1938.

Rządkowski J., Pierwszy Legion Putawski, Warszawa 1925.

Wrzosek M., Polskie korpusy wojskowe w Rosji w latach 1917-1918, Warszawa 1969.

Wrzosek M., Wojskowość polska podczas pierwszej wojny światowej (1914-1918), [w:] Zarys dziejów wojskowości polskiej w latach 1864-1939, red. P. Stawecki, Warszawa 1990, s. 121-226.

Zgórniak M., Iwaszkiewicz-Rudoszański Wactaw, [w:] Polski Stownik Biograficzny, t. 10, Wrocław 1962-1964, s. 184-185.

\section{Netografia}

http://www.ria1914.info/index.php/Гедеванов Николай Константинович [dostęp: 15 XI 2019]. 


\section{Witold Jarno}

\section{REGROUPING OF THE $3^{\text {RD }}$ POLISH RIFLEMEN DIVISION FROM JELNIA TO ŻŁOBIN IN FEBRUARY 1918}

Summary. The article describes a little-known episode from the history of Polish military formations in Russia during the First World War. It was the march of the $3^{\text {rd }}$ Polish Riflemen Division in February 1918 from Jelnia (near Smolensk) to Żłobin, where was concentrating the First Polish Corps, commanded by general Józef Dowbor Muśnicki. The march of the $3^{\text {rd }}$ Polish Riflemen Division was unique in the history of the Polish Army, because it took place in very difficult weather conditions - through snowdrifts and in frost reaching 30 degrees at night. Division soldiers marched through territories inhabited by hostile people - fighting constantly with Bolshevik troops, who tried to stop and disarm the Polish division. Her soldiers fought numerous fights with the enemy, including the biggest and bloodiest battle at Pobołów. In almost three weeks, soldiers of the $3^{\text {rd }}$ Polish Riflemen Division went over $400 \mathrm{~km}$, reaching the Żłobin region at the end of February. Here they joined with the First Polish Corps in Russia - ending their epic, which was a proof of the great dedication of the Polish soldier to his homeland.

Keywords: Polish military formations in Russia, I-st Polish Corps in Russia, $3^{\text {rd }}$ Polish Riflemen Division, The First World War 